\title{
En musikers møte med de yngste barna i barnehagen
}

\author{
Om ikke å vite på forhånd hvilke ideer som kan komme til å \\ fungere.
}

\author{
Morten Sæther*, \\ Dronning Mauds Minne Høgskole for barnehagelcererutdanning, Trondheim, Norge
}

\begin{abstract}
Sammendrag
Hensikten med studien som presenteres i denne artikkelen er å utforske hvordan en musiker, to barnehagelærere og en forsker og kunstpedagogisk veileder forstår en musikers musikalske møter med de yngste barna i barnehagen. Forskningen baseres på et praksisbasert utviklingsprosjekt, og intervensjonen omfatter seks musikksamlinger. Barnehagelærerne, musikeren og veilederen reflekterer over de musikalske møtene for å finne ut av hva som karakteriserer disse møtene, og for å lære av toddlernes egne uttrykk om hva som kan gi musikkopplevelser. Bourriauds begrep relasjonell estetikk, og Valbergs utvikling av begrepet som relasjonell musikkestetikk utgiør forståelsesramme for analysen. De karakteristiske trekkene i de musikalske møtene som forskningsdeltakerne observerte kan oppsummeres i improvisasjon og skapende medvirkning. En konklusjon er at det ikke er selvsagt at en profesjonell musiker kan bidra til musikkopplevelser. I denne studien har et profesjonelt læringsfelleskap mellom musiker og barnehagelærere bidratt til utvikling av innholdet i de musikalske møtene i dette prosjektet.
\end{abstract}

Nøkkelord: Musikalske møter med toddlere; improvisasjon; barns skapende medvirkning $i$ musikk; relasjonell musikkestetikk; profesjonelle laringsfellesskap

\begin{abstract}
The purpose of the study presented in this article is to explore how a musician, two Early Childhood Education teachers and an arts educational tutor and researcher in an Early Childhood and Care setting understand the musician's encounters in music with the youngest children, the toddlers. The research and development project is practice led, and the intervention embraces six improvised musical encounters. The teachers, the tutor and the musician reflect upon the encounters in order to find out characteristics of the encounters, and to learn from the toddlers about what might produce musical experiences. Bourriaud's notion of relational aesthetics, and Valberg's development of the concept as relational music aesthetics inform the interpretive analysis. The characteristics observed by the research participants regarding the musical encounters in this study can be summed as improvisation and creative participation. It is not granted that a musician can reach out to the toddlers in 'musicking'. In the light of a relational music aesthetics the importance of the dialogue within the professional learning community and the toddlers was of decisive importance in this study.
\end{abstract}

^Korrespondanse: Morten Sæther, DMMH, Thrond Nergaards veg 7, N-7044 Trondheim, Norge. Epost: msa@dmmh.no 


\section{Scether}

Keywords: Musical encounters with toddlers; improvisation; creative participation in music; relational aesthetics in music; professional learning communities

Received: May 2016; Accepted: November 2016; Published: January 2017

\section{Innledning}

De yngste barnas bidrag har en spesiell tiltrekningskraft fordi man som voksen ikke riktig vet hva som kan fungere, hva som får fram latter og smil i noe som kan virke som nonsenskommunikasjon, for eksempel i kunst. I «Småbarnspedagogikkens komplekse komposisjoner» (Sandvik, 2016) fører Sandvik, Johannesen, Larsen, Nyhus og Ulla en samtale med hjelp av noen valgte filosofer omkring barns opplevelser. Deres interesse er å undersøke hva barn kan lære de voksne i barnehagen. Forfatterne er opptatt av «... barns preferanser for å være i åpne, bevegelige prosesser og deres fascinasjon for nonsens.» (Sandvik, 2016, s. 42). I denne artikkelen støtter jeg meg på Bourriauds (2008) tanker om relasjonell estetikk i en analyse av hva noen voksne ser $i$ en musikers møte med barnehagens yngste barn (toddlerne), i musikksamlinger der musikeren inviterer barna med i et musikalsk samspill. Hensikten med artikkelen er å undersøke hva voksne ser og muligens forstår av disse mulige, potensielle musikalske møtene, eller bruddene, når de musikalske ideene ikke vekker interesse. Hvordan forstår musiker, barnehagelerer og forsker potensielle musikalske møter mellom musiker og toddlere?

Nasjonalt senter for kunst og kultur i opplæringen (KKS) tok i 2014 initiativ til et utforskende prosjekt om hvordan barnehagen og kunstnere kan utvikle gode kunstmøter i barnehagen. Prosjektet Musiker $i$ barnehagen, som denne artikkelen bygger på, utgjør ett av flere delprosjekter i prosjektet KKS har initiert (KKS, 2015). Dette prosjektet har handlet om å prøve ut innhold, aktiviteter og måter å skape musikk på i dialog med toddlere $\mathrm{i}$ en barnehage. Barnehagen ble plukket ut etter forespørsel fra KKS ut fra at denne barnehagen har vist særlig engasjement for kunstnerisk arbeid. Barnehagen ønsket seg en musiker med annen musikalsk erfaring enn det barnehagen var vant med, og de ansatte ønsket spesielt at de yngste $\mathrm{i}$ barnehagen skulle delta. En jazzmusiker ble forespurt på grunnlag av hans tidligere erfaringer med improvisasjon og eksperimentell musikk. I forkant av prosjektet var det avsatt mye tid til diskusjoner om hva musikksamlingene skulle inneholde, og hva god musikkaktivitet kunne være for toddlere i barnehagen.

Den norske rammeplanen for barnehagen, «Rammeplan for barnehagens innhold og oppgaver» (KD, 2011) poengterer at barnehagen som kunst- og kulturarena skal inneholde kunst og kultur både for, med og av barn. I denne artikkelen analyseres ikke spesifikt de møter som kunne oppstå mellom de involverte, fokus er på musikerens, pedagogenes og den kunstpedagogiske veilederens/forskerens refleksjoner i etterkant av de musikksamlinger som musikeren deltok i. De voksne forskningsdeltakerne reflekterer over toddleres mulighet til å uttrykke seg musikalsk i dialog med en musiker i samhandling med barnehagelærere. 
Toddler er et begrep som brukes om ett- og to-åringer og betyr de som stabber og går (Løkken, 2005, s. 25). Løkken skriver at toddlere opplever og utforsker verden gjennom å erfare med kroppen og bruke alle sine sanser. De utforsker ulike materialer og viser interesse for lyd og fargeklanger. Tidligere forskning (Swanwick, 1998; Young, 1995; Valberg, 2008) poengterer nettopp toddlernes interesse for det karakteristiske med klang (klangfarge) og betydningen av denne interesse i barnets helhetlige utvikling.

I første del av artikkelen presenterer jeg noen eksempler på norsk forskning om små barn og kunst. Begrepene relasjonell estetikk og relasjonell musikkestetikk introduseres som veiledende begreper. Deretter presenterer jeg forskningsdesignet og analysen i denne studien. I artikkelens siste del drøfter jeg hva de voksne har lært om hva som karakteriserer musikalsk samspill som involverer toddlere og hva betydningen av et profesjonelt læringsfellesskap relatert til musikalske møter mellom kunstner og toddlere i barnehagekontekst, kan være.

\section{Forskning om små barn og kunst}

Barnehagens sterke uttrykkstradisjon er basert på barnets frie utfoldelse. Denne uttrykkstradisjonen kommer gjerne i forgrunnen framfor kunstfaglige kunnskaper om virkemidler, teknikker og en bevisst pedagogikk for kunstfaglig arbeid med barn (Sæbø, 2008). Sæbø skriver at barn trenger inspirasjon fra ulike kunstopplevelser og erfaring fra arbeid med forskjellige kunstneriske virkemidler. Med en kunstner i barnehagen er nettopp muligheten til å lære mer om teknikker, virkemidler og refleksjon til stede. Musikeren har høy kompetanse på hvordan han eller hun kan skape varierte uttrykk med bruk av musikalske virkemidler som klang, dynamikk, rytme og tempo (Sæther, 2012).

Forskningsprosjektet «Klangfugl - kulturformidling med de minste» i regi av Norsk kulturråd har vært til inspirasjon for denne studien. Evaluering og dokumentasjon av prosjektet er publisert i Norsk kulturråds rapport «Barnet og Kunsten» (Østberg, 2005) der vesentlige bidrag har vært artikler av Hernes, Os og Selmer-Olsen, også formidlet i boken «Med kjærlighet til publikum» (Hernes, Os \& Selmer-Olsen, 2010). Erfaringene fra prosjektet viser at også små barn har stor glede av kunst, særlig om kunstnerne klarer å 'tone seg inn' mot barna. Kunstnerne har blant annet observert barna i ulike formidlingssituasjoner for å kunne tilpasse rytmen i det kunstneriske uttrykket til målgruppen. Erfaringer fra Klangfugl-prosjektet tydeliggjør noen vesentlige momenter når det gjelder innhold, form og virkemidler i de kunstneriske møtene med små barn. Det blir særlig pekt på betydningen av gjenkjennelse, bevegelse og relasjoner. I tillegg er virkemidler som gjentakelse, tempo, rytme, timing og overraskelse viktig (Hernes, Os \& Selmer-Olsen, 2010).

Annen forskning som har hatt særlig relevans for denne studien er Valbergs (2008) «Konserter med spedbarn som målgruppe» og Hoviks (2014) kunstneriske og teoretiske forskningsprosjekt om teater for de aller minste, «De røde skoene». Felles for disse forskningsprosjektene er at de tar utgangspunkt $\mathrm{i}$ barns egne uttrykk og 


\section{Sather}

væremåte. Siden denne studien handler om tolkning av refleksjoner over musikalske møter mellom en musiker og toddlere, vil jeg kort i det følgende presentere noen perspektiver på toddleres musikalske utrykk.

\section{Musikalsk uttrykk hos toddlere}

Ifølge Løkken (2005) gir toddlere en umiddelbar, sanselig og kroppslig respons på inntrykk og opplevelser. I musikalsk aktivitet for todddlere, de yngste i barnehagen, viser forskning at barn viser særlig interesse for lyd og klangfarge. Barnets eget motiv for musikalske uttrykk i her-og-nå-situasjoner blir da den viktigste faktoren.

Trondalen (1995) legger vekt på en psykologisk forståelse der hun ser lyd som materiale for musikk. Musikk er klingende lyd for vår bevissthet, hevder hun. Lyd blir da mer enn svingninger og bølger. En lignende forståelse finner vi også hos Swanwick (1988) som hevder at fokus i toddlernes musikkopplevelse særlig dreier seg om å persipere lyd som interessant klang. Swanwick utviklet sammen med Tillmann (1986) en spiralmodell som viser sekvenser og særtrekk i den musikalske utviklingen. Spiralmodellen illustrerer forløpet innen området musikalsk komposisjon basert på empiriske undersøkelser i flere kulturer (sitert etter Bonde, 2007, s. 41). Modellen er bygd opp rundt tre prinsipper i musikalsk utvikling som kobles til aspekter ved barns lek. Disse er mestring, imitasjon og fantasilek. Modellen identifiserer også fire dominerende fenomener i hver fase. Disse er materialer, uttrykk, form og verdi. Toddleren vil være i den første fasen, der barnet viser interesse for utforsking av lyd, og etter hvert rytmer. Prinsippene mestring, imitasjon og fantasilek kan også være kriterier for musikalsk samhandling med toddlere. Young (2003) poengterer at fokus og mestring er knyttet til vokalisering og rytmiske bevegelser der barnet viser evne til å imitere korte sekvenser av vokale og spilte rytmer. Small (1998) er inspirert av balinesisk musikkforståelse der musikken ikke oppfattes som et enestående kunstverk, men at meningen med musikk er aktiviteten. Musikk blir til når den gjøres og deles. Small (1987) bruker derfor begrepet musicking som oppfattes mer som et verb enn et objekt. Han forklarer begrepet slik:

Music is not primarily a thing or a collection of things, but an activity in which we engage. One might say that is not properly a noun at all; but a verb (Small, 1987, s. 50). Uttrykk i her-og-nå-situasjonen som viser seg i umiddelbar, sanselig og kroppslig respons på musikk, blir vesentlig. Opplevelsen er det sentrale og kan, ifølge Løkken (2005), beskrives som en persepsjonens fenomenologi. Ut fra en fenomenologisk forståelse vil musikalske møter handle om hva barnet opplever her og nå.

Refleksjonene som utgjør empirien i denne studien, fokuserer på musikalsk samspill, og derfor kan relasjonell (musikk)estetikk forstås som veiledende begrep i analysen.

\section{Relasjonell estetikk og relasjonell musikkestetikk}

Kunstkritikeren og kuratoren Bourriaud knyttes gjerne til begrepet relasjonell estetikk og 1990-tallets kunstpraksiser. Han har skrevet boken «Esthetique relationelle», hvor han peker ut en ny type kunst der vekten ligger på kunstens sosiale funksjon og på kunstverkenes flyktige og fluktuerende karakter. Bourriaud bruker begrepet 
relasjonell kunst om «[k] unstneriske praksiser som tar mellommenneskelige relasjoner og deres sosiale kontekst som teoretisk og praktisk utgangspunkt /. ./» (Bourriaud, 2007, s. 165). Bourriaud beskriver relasjonell estetikk som en «[e]stetisk teori som består i å bedømme kunstverkene i funksjon av de mellommenneskelige relasjoner de forestiller, produserer og fremkaller» (s. 165). Bourriaud framhever møtet med kunstuttrykket som mer viktig enn kunstuttrykket i seg selv og mener at samtidskunstens form inviterer til kontinuerlig møte. Begrepet relasjonell estetikk er skapt med tanke på kunstgallerier, og begrepet er kritisert og diskutert blant annet ut fra politiske perspektiver på hverdagsliv og kunst (Bishop, 2002; Dezeuze, 2006; Martin, 2014). I norsk kontekst har begrepet fått en utvidet betydning til bruk om interaksjon mellom kunstner, kunstpedagog og deltakere. Holdhus (2015) har brukt begrepet i drøfting av skolekonserter med elever som publikum. Böhnisch (2013) har brukt begrepet $\mathrm{i}$ forbindelse med teater for de aller yngste. Jeg er i denne studien inspirert av måten Valberg (2008) vektlegger det relasjonelle gjennom bruk av begrepet relasjonell musikkestetikk. Han skriver om musikk som et relasjonelt fenomen. I en relasjonell musikkestetikk vil uttrykk som «samvær, årvåkenhet, lytting, deling, intersubjektivitet» få betydning, skriver Valberg (2010, s. 176). Videre skriver Valberg om konserter for barn: «For å få den andre i tale må det relasjonelle verket by opp til samhandling med gester ... som klar, leken og forhandlende.» (s. 176) Han mener at relasjonen mellom barnehagebarn og voksne er et særlig sentralt aspekt i barns kunstopplevelse. Valberg (2010) skriver også om deltakerstrategier i det han kaller en relasjonell musikkestetikk, og han nevner spesielt «hen-vendelsen» til barn som gestisk, for eksempel et blunk eller en kremting. Slik Valberg ser det, er alle de tilstedeværende i kunstformidlingssituasjonen viktige fordi de påvirker situasjonen og opplevelsen. I barnehagen er det relasjonelle aspektet helt sentralt i kunstfaglig arbeid. I linje med Valbergs tenkning foreslår jeg at barns opplevelse i møte med kunstnerisk uttrykk, er avhengig av, hvordan de voksne omsorgspersonene forholder seg til barnet i formidlingssituasjonen. Dette krever en tilstedeværelse der omsorgspersonene lytter til barnet og selv er fokusert på det som skjer i kunstformidlingen. Dermed spør jeg i denne studien hva de voksne kan lære av og om barnet i møte med kunst og utøver. Den voksne kan ha en rolle gjennom å være 'støttende stillas', men også noen ganger delta aktivt. Omsorgspersonenes rolle blir viktig å avklare med kunstnerne i forkant av en kunstformidlingssituasjon. (Hernes, Os \& Selmer-Olsen, 2010) Personalets holdninger til kunstuttrykkene og felles forberedelser og etterarbeid rundt en musikkaktivitet antas være en vesentlig del av kunstopplevelsen i prosjektet Musiker i barnehagen. De voksne er invitert til å lære av og med barn og musiker.

\section{Forskningsdesign knyttet til prosjektet Musiker $i$ barnehagen}

\section{Mål for prosjektet og problemstilling for studien}

Mål for kunstneren i det større prosjektet Kunstner $i$ barnehagen er formulert som å få større forståelse for målgruppen, å få nye impulser til nytt materiale, å beholde egen åpenhet og spontanitet i møte med barna, og å kunne ta mot impulser og hele tiden 


\section{Sather}

se om de kan tas videre. Mål for barnehagepersonalet er formulert som å lære noe nytt innenfor improvisasjon, å bli kjent med kunstner og å knytte relasjoner. (Sæther, 2015, s. 6)

Problemstillingen for analysen i denne studien er følgende:

Hvordan forstår musiker, barnehagelerer og forsker potensielle musikalske møter mellom musiker og toddlere?

Som underspørsmål spør jeg $i$ analysen: Hva karakteriserer disse musikalske møtene? Når fører musikerens ideer til deltakelse blant barna?

\section{Forskningsdeltakere}

Forskningsdeltakerne utgjør de voksne deltakerne i det kunstneriske utforskningsprosjektet. To barnehagelærere byttet på å delta sammen med vanligvis ett til tre barn i alderen 1-2 år. Jeg kaller de to voksne A og B; barnehagelærer (A) med ca. 20 års erfaring fra barnehage og barnehagelærer (B) med to års praksis og med master $\mathrm{i}$ førskolepedagogikk. Barnehagelærerne har ingen kunstfaglig utdanningsbakgrunn ut over sin barnehagelærerutdanning. Musikeren har ingen erfaring fra kunstnerisk arbeid med barn i barnehagealder før dette prosjektet. Musikeren har derimot mye erfaring som utøvende perkusjonist og jazzmusiker. Han representerer en gehørbasert utøvertradisjon som han selv opplevde som særlig relevant for musikalske møter med de yngste barna. Kunstneren, som hadde vært utøvende ved store konserter både i og utenfor Norge, var foran oppgaven usikker på å improvisere sammen med toddlere. Jeg fungerte både som kunstpedagogisk veileder i prosjektet og som forsker i denne studien. Toddlerne er en selvfølgelig del av prosjektet. Forskningsetiske retningslinjer er fulgt, blant annet med klarering til Norsk samfunnsvitenskapelig datatjeneste (NSD). I alt deltok ni toddlere fra barnehagen i prosjektet Musiker i barnehagen.

\section{Et kunstnerisk utforskningsprosjekt}

I kunstneriske utforskningsprosjekter kan forskeren ha rollen som både forsker, kunstner og pedagog. Hovik (2014) viser nettopp en slik forskerposisjon der hennes rolle har vært tredelt. Hun peker på ulike identiteter der rollene er vevd sammen, og der rollene bytter plass i prosessen. «Å trekke skarpe skillelinjer mellom de ulike rollene $\mathrm{i}$ en kunstnerisk forskningsprosess skaper derfor unødvendige hinder $\mathrm{i}$ den skapende prosessen» (Hovik, 2014 s. 87). En modell som Hovik benytter for å illustrere dette, bygger på en grunnmodell som er hentet fra Neelands (2006) med tre sirkler omfattende rollene kunstner, pedagog og forsker. I prosjektet Musiker $i$ barnehagen har rollene vært tydelig atskilte $\mathrm{i}$ og med at rollene har vært fordelt på ulike personer. I den praktiske prosessen har forskningsdeltakerne hatt tydelig atskilte oppgaver, mens i refleksjonsmøtene har roller og posisjoner overlappet hverandre. Inspirert av de tre rollene Hovik har beskrevet, kan modellen vist i figur 1 illustrere forskerposisjonen der refleksjonsmøtene består av ulike roller i dialog.

\section{Metode i det kunstneriske utforskningsprosjektet}

Forskningen knyttet til prosjektet kan karakteriseres som praksisledet, og empirien er tett knyttet opp mot praksisen som er prøvd ut. Ansatsen er tolkende med relasjonell musikkestetikk som en veiledende optikk i forskerens beskrivelser og tolkninger. 


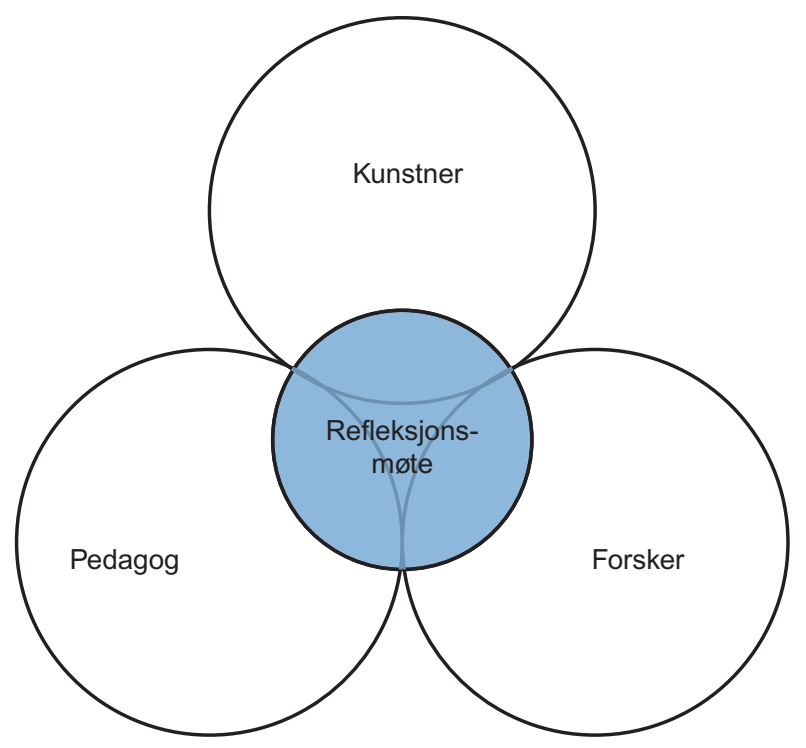

Figur 1. Modell for kompetanseutvikling gjennom refleksjonsmøter

Analysen av det skriftlige materialet som er generert, er gjennomført som en tematisk analyse.

\section{Musikksamlinger og refleksjonsmøter}

Det ble gjennomført seks musikksamlinger med musikeren; hver musikksamling bestod av tre episoder etter hverandre som vanligvis inkluderte en til tre toddlere. I det kunstneriske utforskningsprosjektet vekslet to barnehagelærere på å delta med støttefunksjon for barna i musikksamlingene. I løpet av utforskningsperioden ble det gjennomført et planleggingsmøte og i alt seks refleksjonsmøter i etterkant av musikksamlingene. Etter hver musikksamling ble det gjennomført et refleksjonsmøte. Musikeren reflekterte over egen opplevelse av ulike musikalske episoder i musikksamlingene, i dialog med barnehagelærernes refleksjoner på grunnlag av deres deltakelse i og observasjoner av det musikalske samspillet. I løpet av de seks samlingene ble det gjort sporadiske videoopptak til internt bruk for å studere det musikalske samspillet nærmere. I etterkant av møtene formulerte deltakerne sine skriftlige refleksjoner. De nedskrevne refleksjonene har handlet om hva som karakteriserer det musikalske samspillet mellom musikeren og toddlerne i barnehagen. Refleksjonsnotatene er samlet i to prosjektrapporter, en fra barnehagelærerne og en fra musikeren. Rapportenes første del inneholder beskrivelse av innhold og gjennomføring, mens rapportenes andre del inneholder refleksjonsnotatene som utgjør empirien i denne studien. Refleksjonsnotatene er skrevet som en sammenhengende tekst.

Ved første felles refleksjonsmøte konkluderte deltakerne med at musikeren ikke skulle gjennomføre en «konsert» for barna, men heller skape musikalske samvær der barna skulle få være kreative med-skapere. Det ble videre diskutert og avklart hvilke roller musikeren og barnehagelærerne skulle ha i den skapende prosessen. 


\section{Sather}

Barnehagelærerne skulle ikke delta direkte i det musikalske samspillet med egne initiativ. De skulle vise interesse og delta musikalsk om det føltes naturlig, men hovedsakelig være til stede som støtte for barnet.

\section{Forskerrollen}

Med lang erfaring fra egen musikkundervisning og veiledning i barnehagelærerutdanning har jeg en forforståelse som ligger til grunn for tolkninger i den analytiske prosessen. Den omfatter blant annet kjennskap til tidligere forskning og litteratur og erfaring fra egen utøvelse. Jeg har forventninger til hva som oppleves som relevant i sammenheng med analyse og tolkning av empirien. Min forforståelse preges også av at jeg har vært veileder for dette utviklingsprosjektet. Veilederrollen har i denne sammenhengen dreid seg om de ytre rammene for prosjektet. Det har vært musikeren og barnehagelærerne som har utviklet selve innholdet i aktivitetene. I analyseprosessen speiles refleksjonene jeg har gjort meg i dialog med egne observasjoner av praksiser, og observasjoner jeg har gjort gjennom tilstedeværelse ved to av refleksjonsmøtene i prosjektet. I tillegg har jeg observert noen av kunstnerens musikalske møter med toddlerne. Jeg har også sett videoopptak fra musikksamlinger som jeg selv ikke var til stede på.

\section{Refleksjonsmøter som profesjonelt læringsfellesskap}

Refleksjonsmøter slik de er gjennomført i denne studien, kan beskrives som et profesjonelt læringsfelleskap. Helstad (2014) beskriver profesjonelle læringsfellesskap som en kollektiv kunnskapsutvikling gjennom en forskende tilnærming og mot til å utvikle praksisene, noe som forutsetter vilje til samarbeid og gjensidig tillit. Earl og Timperley (2008) fremhever kvaliteten på samtalene som avgjørende for om kunnskapsutvikling foregår. De skiller mellom svak og sterk refleksjon og skriver at samtaler i seg selv like gjerne kan fungere hemmende som fremmende for kunnskapsutvikling. Sterke refleksjonsformer preges av at relasjoner utfordres, skriver Earl og Timperley (2008), og forutsetter kommunikasjon der det anses legitimt å utfordre eller kritisere hverandre, der det etterstrebes en balanse mellom støtte og utfordring, og der det fins et undersøkende fokus på substansielle forhold. I denne studien har forskningsdeltakerne utfordret og bygd videre på hverandres innspill. Dette skyldes sannsynligvis at de har utviklet en trygghet til hverandre gjennom deltakelse i det eksplorative kunstprosjektet. Schön (2001) beskriver blant annet to typer reflekterende praksiser som metode innen profesjonsutvikling. Refleksjoner i musikerens utøvende praksis i møte med barna i her-og-nå-situasjoner kan beskrives som refleksjon $i$ handling, og musikerens og barnehagelærernes felles refleksjoner $\mathrm{i}$ etterkant av musikksamlingene beskrives som refleksjon over handling.

Hver enkelt av forskningsdeltakerne har skrevet ned sine personlige refleksjoner basert på både erfaringer fra musikksamlingen og deltakelse i refleksjonsmøtene. Flere runder med refleksjoner har gitt mulighet for mer gjennomreflektert forståelse av hva som karakteriserer musikksamlingene og hva de voksne har lært om og av toddlerne, samt hva slags relasjoner som bidrar til at samspillet fungerer eller leder til brudd og manglende interesse. 


\section{Analyse av refleksjonsnotater og observasjoner}

Analysearbeidet kan sies å ha vært en kontinuerlig prosess ettersom jeg var med på planlegging av musikksamlingene. Observasjoner fra to refleksjonsmøter og ett planleggingsmøte har gitt muligheter for bedre å forstå innholdet i refleksjonene. Jeg har i den innledende analysefasen gjentatte ganger lest de nedskrevne refleksjonene slik de er framstilt i forskningsdeltakernes refleksjonsnotater. I en tolkende analyse kan denne fasen karakteriseres som en «naiv tolkning». Fra den naive tolkningen har jeg beveget meg mot en mer «moden tolkning» gjennom en tematisk analyse (Westlund, 2015, s. 76).

\section{Tematisk analyse}

Gjennom en innholdsanalyse (Cavanagh, 1997; Fauskanger \& Mosvold, 2014) av teksten kodet jeg det jeg oppfattet som sentrale begreper knyttet til forskningsspørsmål og til de mål forskningsdeltakerne selv hadde satt for prosjektet. Det er imidlertid vanskelig å identifisere andre fenomen enn dem man først legger merke til, særlig dersom en allerede på forhånd har en bestemt oppfatning av det som uttrykkes (Tjora, 2013). At mitt hovedsakelige analysemateriale var deltakernes skriftlige refleksjonsnotater, sikret en viss forskerdistanse til materialet. Optikken med begrepet relasjonell musikkestetikk hjalp meg også til å prøve å være åpen for nye aspekter $\mathrm{i}$ analysen. I artikkelen bruker jeg sitater fra refleksjonene slik de kommer til uttrykk i refleksjonsnotatene og i mine obsrevasjoner, som illustrasjon og som validering av analysen. Det er mitt forskerblikk med bakgrunn $i$ teori og egen praksis som tolker refleksjonene som uttrykk for en relasjonell musikkestetisk innstilling. En estetisk innstilling beskrevet som en relasjonell musikkestetikk, inkluderer i denne sammenhengen å se verdien av et musikalsk samspill der alle involverte får betydning for det kunstneriske uttrykket.

Gjennom analysen har jeg kunnet artikulere en oppfatning av de prosessene som har foregått i praksis. Disse dynamiske prosessene har allikevel gjort det krevende å finne mønstre og sammenhenger, men samtidig har jeg hatt rik tilgang på informasjon om hvordan musikeren og barnehagelærerne har reflektert over hva som gir mening i det musikalske samspillet i prosjektet, og hva toddlerne har lært dem. Jeg har som eksempel en observasjon knyttet til toddlernes oppmerksomhet og musikerens valg:

Barn som er ett eller to år gamle vandrer. De stanser opp en stund når noe vekker deres oppmerksomhet. Så kan de gå bort, men komme tilbake etter en stund. Musikeren arbeidet først ganske famlende med grupper på cirka fem barn, men fant ut at det ikke gikk an å ha en god musikalsk kommunikasjon med så mange barn samtidig. Da valgte musikeren i samråd med barnehagepedagogene å ha musikksamling med ett eller to barn om gangen. [Veileder/Forskerobservasjon]

Jeg søkte først svar på de to underspørsmålene for analysen: Hva karakteriserer disse musikalske møtene? Når fører musikerens ideer til deltakelse blant barna? I refleksjonene utkrystalliserte det seg noen tilbakevendende temaer både hos musikeren og hos barnehagelærerne. Kommentarer, utsagn og oppfatninger som viste tydelige sammenhenger ble kategorisert som «tematiske kluster», inspirert av musikalsk 


\section{Sather}

terminologi. En kromatisk toneklynge innenfor et avgrenset område som klinger sammen, danner i musikalsk sammenheng et kluster. I det følgende beskriver og tolker jeg to tematiske klustere som jeg har kunnet konstruere basert på kodningen av materialet, nemlig improvisasjon og skapende medvirkning. Disse funnene knyttet jeg deretter til en drøfting av problemstillingen. De karakteriserer det musikalske samspillet og viser de voksnes forståelse av de relasjonelle aspektene av samspillet, både når det fungerte og når det ble et brudd og toddleren mistet interesse for samspillet. I dokumentasjonen av analysen av tematisk kluster improvisasjon bruker jeg kun musikerens og forskerens utsagn, mens jeg i tematisk kluster skapende medvirkning primært bruker utsagn fra barnehagelærerne.

\section{Tematisk kluster improvisasjon}

Improvisasjon i denne studien handler i hovedsak om musikalsk improvisasjon, men også om barnehagelærerens improvisasjon i samspillet med barnet i musikksamlingen. Musikerens ekspertise omfatter særlig improvisasjon, noe som kan gi muligheter til en god inngang for å skape samspill. Barnehagelærerne og musikeren viser en bred forståelse av begrepet musikk. Dette gir en rikere tilgang for flere uttrykksmuligheter med de yngste i barnehagen. Dette baseres på deres holdning til at alle barn er musikalske, selv om musikaliteten kan arte seg ulikt.

Musikeren har gjennom en reflekterende praksis i her-og-nå-situasjoner anvendt varierte musikalske virkemidler i de musikalske møtene med barna. En veileder/ forskerobservasjon viser dette:

I begynnelsen tok musikeren med seg mange instrumenter, men etter hvert ble det færre og færre musikkinstrumenter. Han kunne feste en bjelle rundt den ene ankelen og lage en grunnrytme med denne foten. Etter hvert tok musikeren i bruk elementer som fantes i rommet som rytmiske lydkilder. Han skapte blant annet rytmer med trommestikker som han trakk fram og tilbake over radiatoren og han brukte på og av funksjonen til en vannkran som laget en svisj-lyd. Barnet var hele tiden i sentrum der musikeren inviterte til samspill gjennom musikalske innspill til nye klang- og rytmeuttrykk. Alt dette vekket barnas interesse og de imiterte og eksperimenterte, mens musikeren tilpasset rytmene til det barna gjorde. [Veileder/ Forskerobservasjon)]

Fra en litt usikker, søkende begynnelse kunne musikeren etter hvert tone seg inn mot toddleren. Musikeren utvider da innholdet i den musikalske improvisasjonen ved å ta i bruk elementer som finnes i rommet, som for eksempel dørhåndtak, radiator og vask. Når det fysiske miljøet trekkes inn i improvisasjonen og samspillet, vil også dette kunne ha en relasjonell betydning.

Dette prosjektet har krevd kan en tydelig tilstedevcerelse og evne til spontane initiativ og responser. Musikeren poengterer at det viktigste har vært å være en dyp lytter. Underveis har musikeren improvisert ut fra her-og-nå-situasjoner og intuitive handlinger, eller med andre ord, underveis-refleksjoner basert på erfaring og kunnskap. Musikeren skriver: 
Samspillet vi laget, var høyst uforutsigbart, meget kreativt og blottet for hemninger selv om jeg med jevne mellomrom spilte rytmer og presenterte groover som i mine øyne holdt et høyt kunstnerisk nivå. [Musikerrefleksjon]

Fortløpende refleksjoner underveis i det musikalske forløpet kan betegnes som taus kunnskap. Den tause kunnskapen er taus i verbal forstand, men absolutt ikke i musikalsk forstand. Den intuitive musikalske dialogen musikeren inviterer til, representerer en fortrolighetskunnskap som viser jazzmusikerens profesjonalitet. En forskerrefleksjon kan knyttes til denne fortrolighetskunnskapen:

\begin{abstract}
Nå kunne man ikke se at musikeren var skremt av møte med toddlerne (slik han sa før prosjektet begynte), tvert imot skapte han musikk med kunstnerisk kvalitet og «groove». Det er absolutt ikke noen selvfølge at en profesjonell musiker kan tilpasse seg toddleres situasjon og fange deres interesse. Her tenker jeg at barnehagelærerne har bidratt til å skape trygghet både for ham og barna. Barnehagelærerne gir bidrag til kvaliteten på samspillet med barna. [Forskerrefleksjon]
\end{abstract}

Det musikeren gjør i sin utforskningsprosess, har likhetstrekk med den forskningsmetode Hovik (2014) anvender sin studie, altså en handlende praksis som kunstnerisk forskningsmetode. Musikeren i dette prosjektet utforsker sin egen utøvende kunstpraksis der han reflekterer underveis, noe som viser seg gjennom improvisasjon. Musikeren sier følgende:

En utøvende musikers største utfordring er å være nullstilt og til stede i øyeblikket. Man kan ikke tenke og utøve samtidig. Refleksjon og analyse skal gjøres før og etter, men aldri i løpet av utøvelsen. [Musikerrefleksjon]

Dette kan virke selvmotsigende $\mathrm{i}$ forhold til beskrivelsen av musikerens reflekterende praksis. Men den type refleksjoner musikeren refererer til som «forstyrrende», er den analytiske «refleksjon over handling» som hører hjemme i etterkant av den utøvende aktiviteten. Musikeren beskriver her noe han lærer seg gjennom å forholde seg relasjonelt til toddleren.

En kjerneverdi som tydeliggjøres i refleksjonsmøtene både hos barnehagelærerne og hos musikeren, er betydningen av og evnen til å kunne improvisere. Improvisasjon i betydningen det uforutsette står i denne sammenhengen ikke for at noe absolutt uventet og overraskende skal skje, men heller for noe uforutsett, basert på en musikalsk sjangerbevissthet hos musikeren, og for improviserte handlinger fra pedagogenes side basert på fortrolighetskunnskap. Barnehagelærerne uttrykker for eksempel at noe de lærer av barna, er at improvisasjon handler om å kunne endre fokus og aktivitet ut fra barns spontane innspill og hendelser i samværet med barna.

Musikeren sier at det handler om å kunne lage kunst $i$ øyeblikket. Dette er ikke det samme som en praksis som assosieres med en spontan, overraskende og risikobetont øvelse, slik Steinsholt (2006) uttrykker det. Steinsholt ser klare likhetstrekk mellom improvisasjon og det han betegner som kunstens lek. Improvisasjon dreier som å 


\section{Sather}

sette seg selv på spill, men også om å ta ansvar for å slippe den andre til (Steinsholt 2006, s. 40). Musikeren reflekterer slik:

Det å stille med «blanke ark» uten fordommer, normer og regler for det musikalske samspillet er jo nettopp den egenskapen barn er så heldige å være i besittelse av. Denne overføringsverdien er gull verdt for en utøvende musiker. For oss er målet å være så ærlige og til stede i situasjonen som overhode mulig, samtidig som fantasien skal kunne flyte fritt. Det å samarbeide med barn blir derfor en veldig nyttig trening på fokus og tilstedevcerelse. Barn er de mest erlige og oppriktige lytterne og deltakerne en musiker kan omgås med. Det er blant annet derfor slike prosjekter er viktige også for kunstneren. [Musikerrefleksjon]

Å være ærlig og oppriktig i musikalske møter med toddlere ser ut til å være en gjensidig sak, noe som gjør at det blir et musikalsk møte mellom kunstner, musikk og barn. Valberg skriver at barns deltakerstrategier preges av at barn ikke har de voksnes kulturelle læring om hvordan man skal oppføre seg (på konsert).

Musikeren skriver følgende:

Gjennom klapping, tramping og stemmebruk kjennes lyd og rytme fysisk på kroppen. Det å spille litt på de fysiske bevegelsene en lyd fører med seg, var noe jeg bevisst brukte med barna. Med variasjoner innen tonehøyde og dynamikk som for eksempel å variere med sterke, svake, lyse og mørke lyder som produserte ulike vibrasjoner, så kunne barna få føle musikken direkte på kroppen. [Musikerrefleksjon]

Musikeren poengterer i flere refleksjoner at begrepet improvisasjon ikke bare knyttes til det å utøve jazzmusikk. Det er formidleren av musikk, uansett sjanger, som tar i bruk improvisasjon som et kunstnerisk virkemiddel i kommunikasjonen. Følelsen musikeren har til publikum, i denne sammenhengen representert ved toddlere og barnehagelærere, blir det sentrale utgangspunktet for improvisasjonen (Baily, 1992). Ut fra en slik forståelse av utøvelse viser musikeren at det relasjonelle aspektet vil ha betydning for det kunstneriske uttrykket.

Musikeren flyttet fokus fra verbal kommunikasjon over til musikalsk kommunikasjon etter hvert. Musikeren kommenterer følgende:

Det musikalske samværet skulle handle om kommunikasjon gjennom lyd og rytmer.

Med de yngste barna i barnehagen som deltakere lå det «begrensninger» $\mathrm{i}$ bruk av verbalspråk som viste seg å være gull verdt. [Musikerrefleksjon]

Musikeren opplevde etter hvert at barna og han kunne «snakke» sammen gjennom lydene de laget. Musikeren responderte på barnas lyd og bevegelse, noe som overrasket og engasjerte barna. Innimellom improviserte musikeren fram groover (rytmer) som han tilpasset barnas musikalske innspill.

Musikeren kommenterer:

Her kommer det tydelig til uttrykk at nærhet til egen stemme og den kroppslige tilnærming i det musikalske åpner opp for en relasjonell musikkaktivitet. Den relasjonelle tilnærmingen kan åpne for barns initiativ til egne skapende uttrykk. [Musikerrefleksjon]

Improvisasjon handler også om en type taus kunnskap, en kunnskap som uttrykkes gjennom den musikalske improvisasjonen. Kunnskap kan sies å være taus dersom 
den ikke uttrykkes eksplisitt (Polanyi, 2000). På samme måte kan musikeren være fortrolig med musikalske improvisasjoner uten at han reflekterer bevisst over alle valgmulighetene. Denne implisitte kunnskapen hos både musiker og barnehagelærere blir artikulert i handling, om ikke alltid verbalt, i dette kunstprosjektet.

\section{Sammenfatning av det tematiske klusteret improvisasjon}

Gjennom analysen av forskningsdeltakernes refleksjoner innenfor det tematiske klusteret improvisasjon har jeg identifisert begreper som sammen kan tydeliggjøre hva klusteret improvisasjon inneholder. Begrepene fra analysen er notert med kursiv og omfatter tilstedevarelse, initiativ, timing, dyp lytting, komponering $i$ øyeblikket, spontan kroppslig og sanselig respons.

I utforskningsprosjektet i barnehagen viser refleksjonene til deltakerne en forståelse som er i tråd med Valbergs oppfatning av relasjonell musikkestetikk og med Smalls musikksyn. Musikeren benytter improvisasjon som en kjerne i musikerens tilnærming til å skape kunstuttrykk i samspill med barna.

Den kroppslige, sanselig sterke og umiddelbare musikkopplevelsen kjennetegner ikke minst ett- og to-åringers omgang med musikk. Man kan se barn gyngende eller snurrende som ivrige deltakere når noe gjenkjennbart dukker opp (Vist, 2005). Kroppen er utgangspunktet for at musikken kan la seg sanse. Følelser og musikk blir noe virkelig når kroppen inngår $\mathrm{i}$ dialog med dem.

$\AA$ ha noe kunnskap om målgruppen, som i denne sammenhengen er toddlere $\mathrm{i}$ barnehagen, kan øke kunstnernes bevissthet om egne forutsetninger, verdier og forestillinger, og at en slik erkjennelse ikke nødvendigvis omgjør kunst til pedagogikk (Valberg, 2008). Musikeren har gjennom refleksjonsmøter med barnehagelærerne og gradvis mer praktisk erfaring fått utvidet sin kunnskap om toddleres uttrykk og væremåter. Dette kan ha vært avgjørende for innhold i hans musikalske improvisasjoner med barna.

Musikerens musikkforståelse vises gjennom hans kroppslige tilnærming til musikk. Som jazzmusiker har han tilnærmet seg utøving på trommer og perkusjonsinstrumenter gjennom nærhet til stemmen, og alle andre musikkinstrumenter vil på en måte være som en omvei til musikken han ønsker. I praksis handler det om at kropp og stemme er tydelig til stede i improvisasjonene der musikkinstrumenter og andre lydkilder blir en forlengelse av disse.

\section{Tematisk kluster skapende medvirkning}

Skapende medvirkning handler om at barn skaper sin egen kultur gjennom lek og estetiske $^{1}$ uttrykk, og gjennom estetisk innstilling til livet. Medskaping er en viktig faktor i barns danningsprosess (Amundsen, 2011). Den musikalske samværsformen med musikeren i denne studien har vært basert på interaksjon. Det har vært et musikalsk samvær der musikken oppleves, deles og utføres her og nå.

Musikk kan gjøres, høres eller fremkalles i bevisstheten ved at den aktiverer det indre hørselsbildet, men det kreves uansett en aktivitet for at den kan bli til. Med en slik musikk-

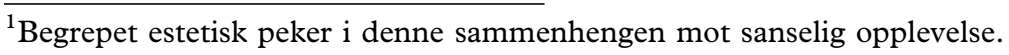




\section{Sather}

forståelse blir barns aktivitet viktig i musikkopplevelsen. Varkøy (2009) tolker Smalls begrep musicking som en prosess der vi forteller historier om relasjoner mellom mennesker og om oss selv. Det relasjonelle aspektet har derfor betydning for kunstforståelsen.

Musikerens musikkforståelse inkluderer det relasjonelle aspektet, noe som har vært avgjørende for tilnærmingen til det musikalske samværet, nettopp som samvær, og ikke som konsert. Barnehagelærer (B) skriver følgende om hvordan en forbipasserende kommenterer det musikalske samværet:

Det banker på døra til avdelingen der musikeren var i full aktivitet med lydutforsking med tre av de yngste barna. En barnehagelærer fra naboavdelingen lurer på når det hele skal begynne? Musikeren svarer at vi har holdt på lenge, vi, og det er like før de skal avslutte. [Barnehagelærerrefleksjon]

I refleksjonsnotatene uttrykker barnehagelærerne at de yngste barna kan medvirke i musikkuttrykkene, og ikke bare være tilhørere. I prosjektet Musiker $i$ barnehagen er nettopp barns medvirkning det sentrale. Barnehagelærer (A) beskriver skapende medvirkning slik:

Jeg endret syn og forventninger til de musikalske møtene med barna. Det har handlet om å skape kreative prosesser der barn kunne få utvide sine forståelser og oppdage nye måter å uttrykke seg på. Det har gitt mulighet for barns medvirkning $\mathrm{i}$ kunstneriske uttrykk. Også de voksne har måttet bryte med sine handlingsmønster og tidligere forståelser for å kunne utvide og skape slike kreative prosesser. Det har gitt grunnlag for barns reelle muligheter til å være medvirkende $\mathrm{i}$ kunstneriske uttrykk. [Barnehagelærerefleksjon]

Musikeren gir barnet mulighet til å bidra med personlige uttrykk og på den måten ha en direkte medbestemmelse. Ingen uttrykk blir «gale», da hvert initiativ eller hver respons blir en del av et kontinuum i et improvisatorisk musikalsk forløp. Det lydlige, sansbare, estetiske blir gjennom gjensidig lytting, musikerens evne til å 'tone seg inn' på barnets uttrykk, ta initiativ og gi respons, et helhetlig uttrykk eller en samstemthet i samspillet. Dette tolker jeg som en relasjonell musikkestetikk der et skapende fellesskap står i sentrum.

Barnehagelærer B beskriver barnehagelærernes læring og medvirkning slik: «Der kunstneren var god til å kommunisere med instrumenter, så var barnehagelærerne gode til å tolke barnas uttrykk utover det lydlige». Barnehagelæreren kjenner barna på avdelingen godt og kan tolke barns uttrykk og reaksjoner adekvat, noe som kan bidra til at barnehagelærerens innspill fremmer barns medvirkning.

Å bidra til at barn medvirker, betyr å gi rom for kreativitet, anser barnehagelærerne. De konstaterer at barn gjerne imiterer andre barn eller voksne i sine uttrykk. Det blir viktig at barn får impulser som kan stimulere dem til egne uttrykk. Det vil være av betydning for kreativ utfoldelse eller medskaping at omgivelsene er støttende og bidrar til trygghet for å skape. En tidlig etablert holdningskultur i barnehagen kan omfatte at det er tillatt å eksperimentere og at det er tillatt «å gjøre feil». Barnehagelærerne konstaterer at også toddlere vil merke om det ligger forventninger til prestasjoner $\mathrm{i}$ lufta, slik at barna vil vegre seg for å bidra og i stedet trekke seg unna. 
Sammenfatning av det tematiske klusteret skapende medvirkning

Begreper som går igjen i refleksjonsnotatene og som er kodet inn under det tematiske klusteret skapende medvirkning, er for eksempel 'inntoning', impulser, imitasjon, speiling, kreativ utfoldelse, tillatt å eksperimentere, gjentakelser, støtte, tolkning og samspill.

I kunstformidling for barn i barnehagealder er det kanskje særlig grunn til å legge vekt på relasjonelle aspekter som handler om møtet mellom kunsten og barnet og som inkluderer de ansatte i barnehagen. De involverte i kunstformidlingen er en del av kunstuttrykket, dette er noe mer enn bare å påvirke formidlingen. Barnehagelærerne får en støttefunksjon fordi barna går vekselsvis mellom musikeren og barnehagelæreren under den musikalske aktiviteten. Barna kan føle behov for trygghet og har mulighet til å søke denne hos barnehagelæreren. Barnets «til og fra»- bevegelse vil også påvirke selve musikkopplevelsen. I denne studien viser de voksne at de er interessert i å lære av barna og at de kan artikulere hva de lærer seg.

Refleksjonsmøtene har i denne studien blitt beskrevet som profesjonelt læringsfellesskap som uttrykkes i deltakernes refleksjonsnotater. Analysearbeidet har forholdt seg til to former for refleksjoner, nemlig refleksjon i handling og refleksjon over handling. Musikerens refleksjon i handling inngår i musikerens og barnehagelærerens refleksjon over handling i etterkant av musikksamlingene.

Eksempler på refleksjon $\mathrm{i}$ handling leses $\mathrm{i}$ analyseprosessen som musikerens improvisasjoner, som har inkludert reguleringer, initiativ, responser, gjentakelser og utprøving av musikalske uttrykk i her-og-nå-situasjonen. Dette kommer videre til uttrykk i musikerens refleksjon over handling.

I refleksjonsnotatene uttrykker musikeren at de nye erfaringene han har fått, har bidratt til hans egen kunstneriske utvikling. Han har fått erfaring av å prøve ut og ikke vite. Han har vært med på samspillsforsøk der barnet bare har vandret sin vei og blitt opptatt av noe annet som har vekket barnets interesse. Han har lært hvordan han skal 'tone inn' seg mot barna. Han har fått utvidet sitt repertoar av musikalske uttrykk, noe som han mener kan bidra til nye kunstneriske uttrykk han kan anvende på nye arenaer.

\section{Drøfting og konklusjon}

Funn ut fra analyse av forskningsdeltakernes nedskrevne refleksjoner blir i denne studien samlet under to tematiske klustere som er valg ut som kjernebegreper som karakteriserer de musikalske møtene. Disse er improvisasjon og skapende medvirkning. I avsnittet om forskerposisjon presenterer jeg en modell for kompetanseutvikling gjennom refleksjonsmøter (figur 1). Modellen viser et møtested mellom de ulike rollene pedagog, musiker og forsker, der refleksjonene kan bringe fram ny kunnskap. Selv om forskeren har hatt observatørstatus, har tilstedeværelsen sannsynligvis påvirket samtalene i refleksjonsmøtene. Barnehagelærerne og musikeren har fokusert på barns skapende medvirkning og improvisasjon, og forskeren har ut fra refleksjonene tolket dette som uttrykk for at det relasjonelle aspektet har hatt særlig betydning for det musikalske samspillet. 


\section{Sather}

I refleksjonene tydeliggjøres det at barnehagelærerne har hatt en tilbaketrukket assistentrolle, men at de har støttet barna i de musikalske aktivitetene. Slik Valberg (2008) ser det, er alle de tilstedeværende i kunstformidlingssituasjonen viktige fordi de påvirker situasjonen og er viktige deler av opplevelsen. Dette oppfattes som et uttrykk for en relasjonell estetikk som kan være kjennetegn på kvalitet i musikalske møter og skapende prosesser med toddlere i dette prosjektet. Dette er også et syn Small (1998) deler, og som han uttrykker i beskrivelsen av begrepet musicking, et begrep som understreker at musikken blir til når den gjøres og deles.

Et kritisk blikk på prosjektet kan løfte fram at dette kunstneriske utforskningsprosjekt ikke hører til hverdagen i en barnehage, men representerer "noe ekstra». Hva med betydningen av daglige erfaringer i en relasjonell estetikk? Har de voksne i barnehagen lært noe de kan overføre til andre musikksamlinger hvor det ikke deltar en profesjonell kunstner? Som en fortsettelse på dette prosjektet kunne det være en utfordring å prøve improvisasjon og skapende medvirkning med de voksne som til daglig omgås toddlere $\mathrm{i}$ barnehagen.

Å bidra til barns skapende medvirkning handler blant annet om å møte barns spontane og kroppslige uttrykk (Bjørkvold, 2005; Vist, 2005). Dersom barna skal medvirke, må det være rom for å inkludere barns uttrykk i samspillet, noe musikeren viser til i sine refleksjoner. Musikeren sier at lydutforskning og improvisasjon gir gode muligheter for barns medskaping.

Å kunne improvisere handler om å klare å endre fokus i øyeblikket, sier musikeren. For å få til dette må en være en 'dyp lytter' i den utøvende praksisen. Forutsatt gode musikalske ferdigheter og erfaring, har improvisasjon potensial til å bringe fram rike opplevelser og uttrykk i det musikalske samspillet med de yngste barna. Samarbeidet mellom de to profesjonene, en person med kunstneridentitet og personer med pedagogidentitet, har ut fra forskerens tolkning bidratt til at forskningsdeltakerne gjennom dette prosjektet har utviklet ny kunnskap om hva musikalske møter med toddlere i barnehagen kan være.

Musikeren uttrykker i refleksjonene en åpen holdning til det kunstneriske prosjektet i barnehagen. Hans improvisasjonskompetanse har nok vært vesentlig, og musikeren framhever selv at evne til spontanitet, dyp lytting, timing og tilstedeværelse er grunnleggende om man ønsker at barna reelt skal få medvirke og skape egne personlige uttrykk gjennom samspill. En konklusjon er at en musiker kan bidra til å skape musikalsk aktivitet der barna er medskapende. Det betyr at musikeren må sette seg selv på spill og gi rom for både egne og andres uttrykk.

\section{Betydningen av en relasjonell musikkestetikk}

I barnehagesammenheng er det særlig relevant å kunne diskutere musikk som en handling med betydning $\mathrm{i}$ et her og nå-perspektiv, altså knyttet til opplevelser delt med andre, som hendelse. I arbeidet med de yngste barna i barnehagen ser jeg uformelle opplevelser og læringssituasjoner som vel så viktige som planlagte og tilrettelagte musikkaktiviteter. Barn i barnehagealder uttrykker opplevelser gjennom spontane musikalske eller andre estetiske aktiviteter. 
I kunstformidling for barn i barnehagealder er det kanskje særlig grunn til å legge vekt på relasjonelle aspekter som handler om møter mellom kunsten og barnet og som inkluderer de ansatte i barnehagen. De involverte i kunstformidlingen er en del av kunstuttrykket, dette er noe mer enn bare å påvirke den.

Analysen og tolkningen av de voksnes refleksjoner har bidratt til å uttrykke noe av en taus kunnskap, men vil ikke bli helt dekkende. Både musikerens og barnehagelærernes tause kunnskap representerer mye av kvaliteten i det eksplorative kunstneriske prosjektet. I denne studien har de artikulert noe av denne kunnskapen med fokus på å lære av barns bidrag i musikalsk samspill. Et tentativt svar på problemstillingen for studien er dermed at musiker, barnehagelærer og forsker forstår improvisasjon og skapende medvirkning som aspekter av en relasjonell musikkestetikk med potensial for å skape musikalske møter mellom musiker og toddlere.

\section{Konklusjon}

Gjennom analysen og tolkningen av de voksnes refleksjonsnotater og observasjoner har to temaer særlig framstått som avgjørende for kvaliteten på musikalske møter mellom toddlere og musiker i dette prosjektet, nemlig improvisasjon og skapende medvirkning. Toddlerne har gjennom sine kroppslige og lydlige responser vist når improvisasjonen har inspirert dem til å bidra i dialogen med musikeren.

Det er flere av begrepene i klustrene som utfordrer til mer utforskning av musikalske møter med toddlere, men også med større barn og voksne. Det er for eksempel begrepet 'dyp lytter'- hva betyr det? Hva betyr det å 'tone seg inn'? En kunne også gjøre gjøre mikroanalyser av den kroppslig-lydlig-rytmiske fram-og-tilbake-leken. Dette kunne lede til mer kunnskap om hva en musiker i barnehagen kan bidra med.

To konklusjoner som sammenfatter hva relasjonell estetikk har betydd i prosjektet, kan i hvert fall trekkes ut fra denne studien. Begge konklusjonene kan knyttes til hva de voksne har lært av toddlerne som var del av utforskningsprosjektet.

Den første konklusjonen er: Det er ikke selvsagt at en profesjonell kunstner kan bidra til kunstopplevelser for toddlere. I denne studien har både barnehagelærerne og musikeren vært åpne og villige til å lære av hverandre. Musikeren har vært generøs med å sette seg selv på spill, og gjennom de kunstneriske kvaliteter han kroppsliggjør som musiker, har toddlerne fått mulighet til å uttrykke seg musikalsk.

Den andre konklusjonen er: Refleksjon og musikalsk utforskning i et profesjonelt læringsfelleskap mellom musiker og barnehagelærere, har bidratt til utvikling av innholdet de musikalske møtene $\mathrm{i}$ dette prosjektet. Improvisasjon og gjensidig skapende medvirkning har gitt mulighet for opplevelser og erfaringer gjennom utforskning av klang og rytmer.

\section{Referanser}

Amundsen, H. M. (2011). Dannelsens topologi. I V. Glaser, K.H. Moen, S. Mørreaunet \& F. Søbstad (Red.), Barnehagens grunnsteiner (s. 143-160). Oslo: Universitetsforlaget.

Barnehageloven (2005). Lov om barnehagen. https://lovdata.no/dokument/NL/lov/2005-06-17-64

Baily, D. (1991). Improvisasjon - its nature and practice in music. London: British Library National Sound Archive. 


\section{Sether}

Bishop, C. (2004). Antagonism and Relational Aestetics. October 110, Fall 2004, 51-79.

Bonde, L. O. (2011). Musik og menneske. Introduktion til musikpsykolog. Frederiksberg: Samfundslitteratur.

Bourriaud, N (2007). Relasjonell estetikk. Oslo: Pax Forlag. (Først utgitt på fransk 1997. Oversettelse Bente Christensen).

Bjørkvold, J-R. (2005). Det musiske menneske. Oslo: Freidig Forlag.

Böhnisch, S. (2015). Feedbacksløyfer for svcert unge tilskuere. (Phd.-avhandling). Kristiansand: Universitetet i Agder.

Cavanagh, S. (1997). Content analysis, concepts, methods and applications. Nurse Researcher, 3, 5-16.

Dezeuze, A. (2006). Everyday life, 'relational aestetics' and the transfiguration of 'the commonplace'. Fournal of Visual Art Practice, 5(3), 143-152.

Earl, L. M. \& Timperley, H. (2008). Professional learning conversations. Challenges in Using Evidence for Improvement. United Kingdom: Springer Academic.

Fauskanger, J. \& Mosvold, R. (2014). Innholdsanalysens muligheter i utdanningsforskning. Norsk Pedagogisk Tidsskrift, 98(2), 127-214.

Hernes, L., Os, E. og Olsen, S. I. (2010). Med kjcerlighet til publikum. Kunst for barn under tre år. Oslo: Cappelen Akademisk Forlag.

Helstad, K. (2014). Kunnskapsutvikling gjennom samtaler i tverrfaglige læringsfellesskap. I E. Elstad \& K. Helstad (Red.), Profesjonsutvikling i skolen (s. 134-151). Oslo: Universitetsforlaget.

Holdhus, K. (2015). Skolekonserter - relasjonelle kunstdidaktiske praksiser? Studia Musicologia Norwegia, 41, $87-105$.

Hovik, L. (2014). De røde skoene - et kunstneriske og teoretisk forskningsprosjekt om teater for de aller minste. (Phd.avhandling). Trondheim: Norges teknisk naturvitenskapelige universitet. Det humanistiske fakultet, institutt for kunst- og medievitenskap.

Kloep, M. og \& Hendry, L.B. (2003). Utviklingspsykologi i praksis. Oversatt av K.O. Jensen. Oslo: Abstrakt forlag.

Løkken, G. (s. 24-36, 2005). Toddleren som kroppssubjekt. I S. Haugen, G. Løkken \& M. Røthle (Red.), Småbarnspedagogikk (s. 24-36). Oslo: J.W. Cappelen Forlag.

Martin, S. (2014). Critique of Relational Aesthetics. Third text, 21(4), 369-386.

Neelands, J. (2006). Re-imaging the reflective practioner:towards a philosophy of critical praxis. I J. Ackroyd (Red.), Research methodology for drama education (s. 15-40). Stoke on Trent: Trentham Books.

Nelson, R. (2013). Practice as Research in the Arts, Principles, protocols, pedagogies, 78 Resistances. Hampshire: Palgrave Macmillan.

KD (2011). Rammeplan for Barnehagens innhold og oppgaver. Oslo: Kunnskapsdepartementet.

KKS (2015). Kunstner $i$ barnehagen. Erfaringer fra samarbeid mellom barnehage og kunstner. Bodø: Nasjonalt senter for kunst og kultur i opplæringen.

Polanyi, M. (2000). Den tause dimensjonen. En introduksjon til taus kunnskap. Oslo: Spartacus forlag.

Sandvik, N. (Red.) (2016). Småbarnspedagogikkens komplekse komposisjoner. Laring møter filosofi. Bergen: Fagbokforlaget.

Schön, D. A. (2001). Den reflekterende praktiker. Hvordan profesjonelle tenker, når de arbejder. Randers: Forlaget Klim.

Small, C. (1998). Musicking: the meanings of performing and listening. Hanover, N.H.: University Press of New England.

Small, C. (1987). Music of the common tongue. London: Calder.

Steinsholt, K. På den andre siden av ingensteds - Improvisasjon, kreativitet og ansvar for den andre. I Steinsholt, K. og H. Sommero (Red.), Improvisasjon - kunsten og sette seg selv på spill (s. 23-45). Oslo: N.W. Damm \& Søn.

Swanwick, K. (1988). Music, mind and education. London: Routledge.

Sæbø, A.B. (2008). Kunstfagenes plass i barnehagen. I K. Bakke, C. Jenssen \& A. Berggraf Sæbø (Red.), Kunst kultur og kreativitet (s. 15-42). Bergen: Fagbokforlaget.

Sæther, M. (2012). Musikalsk utvikling - en helhet. I M. Sæther \& E. Angelo (Red.), Barnet og musikken. Innføring $i$ musikkpedagogikk for barnehagelcererstudenter (s. 67-97). Oslo: Universitetsforlaget.

Sæther, M. (2015). Hva kan en kunstner bidra med i barnehagen for å utvikle barnehagen som kulturarena? (s. 17-21) I KKS, Kunstner $i$ barnehagen. Bodø: Nasjonalt senter for kunst og kultur i opplæringen.

Tjora, A. (2013). Kvalitative forskningsmetoder i praksis. Oslo: Gyldendal Akademisk.

Trondalen, G. (1995). Samspill gjennom det musiske. Blad for Norsk forening for Musikkterapi, 22(2), 12-34.

Valberg, T. (2006). Den store konsertopplevelsen. Kristiansand: Universitetet i Agder. 
Valberg, T. (2008). Konsert med spedbarn som målgruppe. I G. Trondalen \& E. Ruud (Red.), Perspektiver på musikk og helse (s. 275-289). Oslo: NMH-publikasjoner.

Varkøy, Ø. (2009). The role of music in music education research: Reflection on musical experience. Nordic Research in Music Education. Yearbook Vol.11, 33-48. Oslo: NMMH- publikasjoner.

Vist, T. (2005). I lyden bor barnet, i barnet bor lyden - Om små barns forhold til musikk. I S. Hagen, G. Løkken, G \& M. Röthle (Red.), Småbarnspedagogikk (s. 75-91). Oslo: Cappelen Akademisk forlag.

Westlund, I. (2015). Hermeneutik. I A. Fejes \& R. Thornberg (Red.), Handbok i kvalitativ analys (s. 71-89). Andra upplagan. Stockholm: Liber.

Young, S. (2003). Music with the under-fours. London and New York: Routledge.

Østberg, T. (2005). Barnet og Kunsten. Oslo: Norsk kulturråd. 